UDC 82-192

DOI https://doi.org/10.32841/2409-1154.2021.48-4.31

\author{
Chernyshov V. V., \\ PhD in Philosophy, \\ Associate Professor at the General Linguistics and Foreign Languages Department \\ National University "Yuri Kondratyuk Poltava Polytechnic"
}

\title{
STUDENT ANTHEM GAUDEAMUS IGITUR: THE PROBLEM OF ORIGIN AND INTERPRETATION
}

Summary. The article focuses on the problem of origin and interpretation of the student anthem Gaudeamus igitur. The problem field of the study encompasses a number of issues: a chronological problem, the problem of origin and original purpose of the text, its sources, social and cultural environment in which the text had originally been created, different intentions and, therefore, interpretations of those who contributed to the text or used it for centuries. A particular object of study is a variety of Gaudeamus igitur variations and their correlation. Considering the research history of the anthem origin, the author comes to conclusion that the hypothesis on the medieval origin of the present text is highly doubtful. Instead he suggests that the text of the seventeenth century origin, and could have originated in Germany, Italy or Netherlands. However, in course of the study, he also suggests that the most likely place the anthem had originated was the city of Jena in Thuringia, in Germany. Concerning the detection of the possible author of Gaudeamus igitur, it should be noted that under the present conditions the authorship of the text has not been established: the author remains unknown, and all the previous efforts to solve this question in a positive way must be recognized as insufficient and invalid. Beside that there has been stated a hypothesis on the collective authorship of the text: in case the hypothesis would be accepted the question on any personal authorship might be cancelled. The second part of the article dedicated to the author's interpretation of the Gaudamus igitur text. The basic statement of the interpretation is a thesis on the Renaissance character of the present text. Renaissance character of the text, however, is based upon an ancient poetical tradition, represented by the names of three Roman poets: Virgil, Horace, and Ovid, which Renaissance humanists considered to be the model tradition. Also it is observed that in their works these Roman poets represent the ideas characteristic for Greek philosophers: Epicurus, Pythagoras, Plato, Aristotle, and Neo-Platonic tradition. The leitmotiv of the anthem is but a rehash of Horatian motive Carpe diem. The anthem, therefore, is a symbolic representation of human life: its intellectual, private, and socio-political dimensions. The last stanza of the anthem focuses on the main obstacles that could hinder from happiness, and unto which "May they perish" is pronounced.

Key words: Gaudeamus, Renaissance student subculture, student anthems, student songs, student subculture ofthe earlyModernperiod, studentsubculture in the MiddleAges, table songs.

Problem statement. It happens sometimes that a text, which has been for a long time in use and therefore looked utterly familiar, turns at a closer examination to be a mystery, opening an abyss of issues and questions which may seem nearly irresolvable. It appears just the same case is with the worldly renown anthem
Gaudeamus igitur which is widely considered to be the most celebrated student anthem of medieval origin. At a closer look it appears that the both history of the text as much as its interpretation represent a considerable problem. The problem encompasses a variety of issues: starting with chronology, origin and original purpose of the text, its sources, social and cultural environment in which it had initially been created, as well as its (probable) evolution due to different intentions and interpretations of those who used the text over centuries, which in its own turn had fostered appearing the different versions of the text, and at last but not least a proper reception and understanding of it today.

Recent studies and publications. It is obvious that the circle of indicated problems is not entirely new, and has already been more or less satisfactory treated in a number of investigations and studies at least since the last quarter of the eighteen century. The nineteenth century made a great contribution to study both the history of the anthem and the meaning of the text. Among the earliest studies, there should be mentioned the works of A.-H. Hoffmann [1], É. Du Méril [2], Robert and Richard Keil [3], W.M.A. Creizenach [4], A. Ellissen [5], H. von Fallersleben [6], T. Greizenach [7], G. Schwetschke [8], L.F.W. Klaas [9], A.P. von Bärnstein [10], G.E. Klemming [11], J. Bolte [12], A. Knopp [13, 14, 15], J. Zupitza [16], L. Erk and F. Böhme [17], and some others. The twentieth century focused primarily on generalisations. Among the generalising works of the twentieth century, there should be mentioned the works of M.J. Friedländer [18], C. Enders [19], S.A. Sobolevskiyi [20], C. Randolph [21], J. Fuld [22], and some others. The most recent publications focus primarily of the interpretation of the text. Thus, for instance L. Lovicelli focuses on rhetorical analysis, correlating the Gaudeamus with the medieval poetry of Carmina Burana [23]. E. Nayden, V. Maksimov and A. Serebrennikova undertake a philological analysis of the text, making an effort to trace a line between two genres - the clerical table song and the corporative hymn - which they believed lie at the foundation of contemporary version of Gaudeamus igitur. They also trace the text back to the fourteenth century [24]. N. Miron offers a local variation of Gaudeamus igitur, traditional his University [25]. Elisabeth Emery analyses Gaudeamus with respect to the late nineteenth century French taverns as a portal to the medieval [26]. A. Lindmayr-Brandl analyses a table song that has the same opening word - Gaudeamus - and often is being considered to be one of forerunners (or an early versions) of the students' anthem [27]. Ukrainian scholars T. Tymoschuk and I. Tymoschuk focus on the contemporary interpretation of Gaudeamus [28]. I. Vakulyk makes an effort to trace the history of Gaudeamus from 
its very origins to becoming a cult anthem of students around the globe [29].

Purpose statement. The purpose of the present paper is to re-examine the history of origin of the student anthem Gaudeamus igitur, and to provide the ways of its possible comprehensible interpretation.

General study. The history of origin of the student anthem Gaudeamus igitur is far from being clear. It is generally acknowledged that the contemporary (canonical) version first was published in 1781 by Kindleben [30]. It is also generally accepted that Kindleben revised a previous version of the song to make it acceptable for the general public [30, p. 52-54]. Yet the Kindleben's version contains lacunas which cannot be explained with mere conventionality. In 1788, the first musical edition came, claiming to reproduce the Kindleben's text [31]. In its contemporary form first the anthem was performed as a part of opera Faust in 1794 in Hannover by Walther [17]. There is also a variation 1799, similar to Kindleben's version, but containing some extra verses [32].

Quest for the initial text included the search for earlier manuscripts and mentions of the anthem by other authors, scattered around literature. The search for earlier manuscripts resulted discovery of three Latin and two German texts which could have served the initial text for both the Kindleben's version and the musical version 1788. Another variation of the anthem is known as Jenenser Blatt vom Jahr 1776, published by Robert and Richard Keil [3, p. 165-167]. This variation differs from later versions $[13 ; 14 ; 15]$. It is also shorter: only six stanzas in five lines each.

Another two, even older but shorter variations are known as the Baron von Crailsheim's and Reyher's. Baron von Crailsheim's version (c. 1750) contains twelve lines of Latin text divided into three stanzas. Reyher's version (first published by Fabricius, who dated it 1745) contains five stanzas in Latin five lines each; each stanza is followed by German translation. There is also a text "Brüder, laßt uns lustig sein..." (1717) by J.C. Günther that is considered to be the oldest German translation of Gaudeamus igitur. Günther's text encompasses six stanzas seven lines each [17, p. 488-492].

Among the mentions of the anthem by other authors, there are often coming up the names of a Dano-Norwegian writer and dramatist L. Holberg (1684-1754), and two German poets S. Brant (1457-1521) and H. Sachs (1494-1576). Three Holberg's comedies-Den ellefte Junii (1723), Erasmus Montanus eller Rasmus Berg (1723), and Kieldereisen (1725) - contain the same words we find in the Gaudeamus igitur [12, p. 529; 14, p. 389]. Brant in Das Narrenschiff(1494) [33] and Sachs in his Gesang der voller Brïder (1568) [34, p. 257] just mention a song named Gaudeamus. It is almost a general convention, however, that the mentions made by Brant and Sachs refer to another Gaudeamus: a famous drinking song written by A. Urcenus (nicknamed Cordus, 1446-1500), which circulated in Germany in the XVI century. The song contains thirty two stances, three lines each [3].

Textual variety and the quest for the initial version inevitably raise a question for authorship. Hasse in his Die Geschichte der Lombardei (1828) calls the author of Gaudeamus igitur some Dominicus Strada, who lived in Bologna in the sixteenth century [35, p. 135], but Schwetschke rejects this version [8]. Kopp had stated the contemporary Latin text is but a translation of Günther's Brüder, laßt uns lustig sein [13; 14], but Sobolevsky disapproved that idea [20]. So the origin of the text can hardly be set with certainty.
Nor better situation is there with the place and time of anthem origin. So, Creizenach says first Gaudeamus igitur was sung to honour Olympia Fulvia Morata [4]. Laukhard alleges that the anthem circulated yet in Luther's times [36]. However, it is possible that Laukhard confuses the anthem Gaudeamus igitur with the song Io io io io Gaudeamus io io by Urceus. The latter had been so widely popular in the sixteenth century that there were even a number of parodies to it, among which and so-called Hymnus paranymphorum (1525) - a parody on Luther's wedding - that opened with words "Io io io io. Gaudeamus. Cum iubilo" [6].

Scholars who considered the time of anthem origin either can be roughly divided into two opposite parties: those who believe in the medieval origin (Hoffmann, von Fallersleben, Creizenach, Schwetschke and some others), as the other party (Kopp, Bolte, Zupitza, Randolph) holds it emerged in the Modern period.

The idea of medieval origin of the anthem is being founded on two versions of the same medieval anthem, published by E. Du Méril [2] and Klemming [11]. The title on the anthem is the same: Du Mépris du Monde / De Contemptu Mundi. However, it shold be noted that although the poetical form of the stanzas looks very similar to the Gaudeamus igitur the meaning of it is just the opposite: it reflects on the traditional medieval topic of the contempt of the fleeting world.

Concerning the place of origin, it should be said that the anthem is most likely of German, or to be even more precise, Thuringian origin.

Gaudeamus igitur enables to be interpreted in different ways. In order to provide a comprehensible interpretation of the text, it seems much more profitable to undertake a literary and historicophilosophical analysis of the text. Classical version of the anthem contains seven stanzas, five lines each. From the linguistic point (apart from some very tiny details) Gaudeamus igitur is doubtlessly a masterpiece: the rhyme, meter, and accentuation everything looks just perfect.

Whatever is believed about the time of Gaudeamus igitur origin, it is clear that it represents anything but the medieval ideas. The represented ideas are rather characteristic for the Renaissance humanism, and can be traced yet further back to the Age of August and the three greatest Latin poets: Virgil, Horace, and Ovid. However, even then, these ideas were neither new nor of their own invention, and could easily be traced back to Epicurus, Pythagoras, and (in a much lesser degree) Plato, Aristotle, and Neo-Platonism.

Even a brief examination indicates that the general intention of the anthem is to represent the idea expressed by Horace with his "Carpe diem" (Carm., I, 11) [37] or Martial's "Vive hodie" (Mart. 1.15) [38]. Another expression of the same mood can also be found in the Bible (see Eccl. 11, 9-10). The anthem is a symbolic picture of life in which there must not be a place for sorrow or any other anxiety.

The first stanza can be repeated again and again as a refrain for the entire anthem. The call to be joyful because we are young is the very essence of the anthem.

The second stanza, however, addresses a very sensitive topic: the topic that can be at once divided into two: first is the idea that any life is sooner or later comes to an end, as the second one is that there is a dignity in each human life according to its final result. Any human life takes an individual - symbolically or really - to an end that can be considered in the categories of "supernus" and "infernus", and will remain such as an eternal result of one's individual life. 
The third stanza is to remind the audience of the shortness of human life. It is really an exhortation to live today, and to live a full, quality life. The end of any human being is the same, but not with the same result. Sooner or later the death will come, and no one will escape its scythe. The time is very short and must not be wasted in vain. The shortness (or brevity) of life is one of the most important things to remember.

The fourth stanza addresses the intellectual life and academia. In contrast with other commentators, I would rather argue that this "academia" is not a formal educational institution, but a lifestyle. The first thing that might come to mind to a Renaissance humanist hearing the word "academia" was the Athenian academy founded by Plato. For the Renaissance people it was a kind of ideal fellowship that united all those who aspired to knowledge and took the pursuit for wisdom as one's life lasting task. Cosimo Medici had even dared creating the Renaissance Academy in Florence.

However, let us get back to the fourth stanza Gaudeamus igitur. At the top of this informal academia are professors, who embody the informal leadership. Then, there are mentioned "each member": one who is a student, and "all members" or the whole corporation of professors and students. The words "Semper sint in flore" indicate the eternal character of the academy: particular members come and go, but the academia remains. All this seems but a reminiscence of Plato: the existence of things depends on ideas, but the ideas do not depend on things, since they are imperishable and eternal.

The fifth stanza addresses private life. At a first sight it can look like as if it represents private life from a masculine viewpoint, through the eyes of man: as men regard women. Certainly, this literal meaning cannot and must not be excluded. Yet the womanhood here is praised rather as a symbol of life itself, just as in the Bible Eva - the literal meaning of whose name is the life itself - is called "the mother of all living" (Gen. 3, 20). It praises virgins and women, which may symbolically signify premarital and marital states. Virgins are endowed with epithets of "faciles (or graciles) and formosae" (a few earlier versions read "facile accessu"- "easily accessed", but it is scarcely the case here). Women are praised for being "tenerae, amabiles, bonae, laboriosae". It seems not without a reason one could admit that these six adjectives symbolically refer to a well known from the late antiquity conception of the six human ages: infancy, childhood, adolescence, youth, settled life, old age, popularised (or even invented) by St. Augustine [39, p. X-XI].

The sixth stanza addresses the social and political life. The reference to republic immediately brings to the Renaissance mind a few things: The Republic by Plato as well as three most powerful republics of the time Venice, Florence, and Genoa. There is also the literal meaning of the word republic, based on its etymology: res publica - public affair. Plato's Republic purposes to represent a model state ruled by the highest ideas of good, justice, and beauty, led by philosophers, guarded by warriors, and sustained by the rest of people. The Renaissance created at least three potent imitations of Plato's Republic: Utopia (1516) by More, The City of the Sun (1602) by Campanella, and The New Atlantis (1626) by Bacon.

In phrase "Vivat nostra civitas" the emphasis, it seems, must be placed not as much on the "city" as on "our": our city is opposed to their city. Again a circle of meanings brings us back to Plato's Republic and St. Augustine's De Civitate Dei. The mention of "Maecenases" brings to mind the old Maecenas, who supported Vergil, Horace, and a number of other lesser poets; and to whom Horace dedicated his Odes, and Vergil his Georgics.
The seventh stanza addresses negative phenomena in student life, which are rather hindering them to enjoy it. Actually, there are mentioned three obstacles for complete happiness, causing "tristitia" - "sadness" and united under the same name of "osores" ("dolores" - var.): "diabolus", "antiburchius", and "irrisores". Devil is the oldest enemy not only of students as students, but of all the humankind. Haters are those who express their hatred openly, as the scoffers or mockers are those who scoff and scold students as well as those who are false student, who just pretend to be a student.

Conclusions. All that has been said enables drawing the following conclusions.

The hypothesis on the medieval origin of the present text is at least highly doubtful. It can be suggested instead that the text is of the seventeenth century origin. It might have originated in Germany, Italy or Netherlands. However, the most likely place of the anthem origin is the German city of Jena in Thuringia.

Concerning the possible author of Gaudeamus igitur, it should be noted that under the present conditions the authorship of the text has not been established. Beside that the other solution to the problem is to accept a hypothesis on the collective authorship of the text: in case the hypothesis would be accepted the question on any personal authorship might be cancelled.

Basic statement for the Gaudeamus igitur interpretation must be a thesis on the Renaissance character of the present text, which however is based and backed by the ancient poetical tradition, represented by the names of three greatest Roman poets: Virgil, Horace, and Ovid, whom Renaissance humanists considered to be a model tradition. Also it should be noted that the latter tradition reproduces the ideas of Greek philosophers: Epicurus, Pythagoras, and (in a much lesser degree) Plato, Aristotle, and Neo-Platonic tradition. Thus, the leitmotiv of the anthem is but a rehash of Horatian motive Carpe diem. It should also be noted that the anthem is a symbolic representation of human life: its intellectual, private, and socio-political dimensions.

\section{References:}

1. Hoffmann A.H. Spenden zur deutschen Literaturgeschichte II. Leipzig, 1844. S. 134.

2. Méril E. Poésies populaires latines du Moyen age. Paris, 1847. P. $125-127$.

3. Keil Rob., Keil Rich. Deutscher Studentenlieder des 17 und 18 Jahrhunderts. Lahr, 1861. S. 97-165.

4. Creizenach W.M.A. Das Gaudeamus und was daran hängt. Verhandlungen der 28 Versammlung deutscher Philologen und Schulmänner. Leipzig, 1872. S. 204-207.

5. Ellissen A. Recenston des Gaudeamus. Göttinger Gelehrten-Anzeigen, 1872. S. 555-559.

6. Fallersleben H. von. Gaudeamus igitur. Eine Studie. Halle, 1872.

7. Greizenach T. Vortrag über das Gaudeamus, gebalten bei der Philologen-Versammlung zu Leipzig, 1872. Verbandlungen Leipzig, Teubnet, S. 203-204.

8. Schwetschke G. Zur Geschichte des Gaudeamus igitur. Halle, 1877.

9. Klaas L.F.W. Gaudeamus igitur. Alma mater. 1880. P. 279-302.

10. Bärnstein A.P. von. Ubi sunt, qui ante nos in mundo fuere? Würzburg, 1881.

11. Klemming G.E. Cantiones morales, scholasticae, historicae in Regno Sueciae olim usitatae. Norstedt, 1887.

12. Bolte J. Die älteste Fassung des Gaudeamus igitur. Vierteljahrschrift für Literaturgeschichte. 1888. S. 248-253, 528-530.

13. Kopp A. Die Entstehung des „Gaudeamus igitur“. Burschenschaftliche Blätter. 1891. V. 5. S. 139-229. 
14. Kopp A. Die Entstehung des Gaudeamus igitur. Burschenschaftliche Blätter. 1892/93. V. 7. S. 242-270.

15. Kopp A. Deutsches Volks- und Studentenlied in vorklassischer Zeit. Berlin, 1889. S. 197-208.

16. Zupitza J. Zur Geschichte des Gaudeamus igitur. Archiv für das Studium der neueren Sprachen und Literaturen. 1891. V. 87. S. 440-444.

17. Erk L., Böhme F. Deutscher Liederhort. 3 Band. Leipzig, 1894.

18. Friedländer M. Das deutsche Lied im 18 Jahrhun. Stuttgart ; Berlin, 1902, II, S. 6.

19. Enders C. Zur Geschichte des Gaudeamus igitur. Euphorion. 1904. S. 391-406.

20. Sobolevskiy S.I. Pesnia Gaudeamus igitur i eya istoriya. Zhurnal Ministerstva narodnago prosvescheniya. Saint-Petersburg, 1905. Vol. 362. S. 539-580.

21. Randolph C.B. Three Latin Students' Songs. The Classical Journal. 1912. Vol. 7. № 7. P. 291-305.

22. Fuld J.J. The Book of World Famous Music: Classical, Popular, and Folk. $5^{\text {th }}$ ed. New York : Dover Publications Inc., 2000. 752 p.

23. Lovicelli L.S. El Gaudemus igitur: una interpretación. Káñina, Revista de Artes y Letras. Univ. Costa Rica, 2005. Vol. XXIX (1 у 2). P. 115-123.

24. Найден Е.В., Максимов В.В., Серебренникова А.Н. «Гаудеамус»: жанровые границы варьирования концептов. Известия Томского политехнического университета. 2011. Т. 318. № 6 : Экономика. Философия, социология и культурология. С. 150-155.

25. Мирон Н.И. Студенческая песня «Гаудеамус». Современная наука: актуальные проблемы и пути их решения. 2014. Вып. 7. С. $140-142$.

26. Emery E. Gaudeamus igitur: Late Nineteenth-Century French Taverns as a Portal to the Medieval. The Year's Work in Medievalism. 2016. Vol. 31. P. 90-103.

27. Lindmayr-Brandl A. GAUDEAMUS, BIBE, BIBE! Singing from Partbooks with a Baton? Tijdschrift Van De Koninklijke Vereniging Voor Nederlandse Muziekgeschiedenis. 2017. Vol. 67. № 1⁄2. P. 213-222.

28. Тимощук T.О., Тимощук I.О. Шляхи формування сучасної інтерпретації гімну студентської молоді «Gaudeamus». Оновлення змісту, форм та методів навчання і виховання в закладах освіти. 2017. Вип. 16. С. 280-282.

29. Vakulyk I.I. Gaudeamus: from Source of Origin to Cult. Linguistic Studies. 2020. Vol. 11. № 2. P. 46-52.

30. Kindleben C.W. Studentenlieder. Aus den hinterlassenen Papieren eines unglücklichen Philosophen Florido genannt gesammelt und verbessert von C.W.K. [0.O.], 1781. S. 52-54.

31. Lieder für Freunde der geselligen Freude. Leipzig, 1788. S. 24.

32. $\mathrm{R}-\mathrm{r}$. Lieder für Freunde der geselligen Freude zunächst für Studierende oder Neues akademisches Liederbuch. Jena ; Leipzig, 1799. S. 239-241.

33. Brant S. Das Narrenschiff. Stuttgart : Philipp Reclam Jun., 1993. $532 \mathrm{~S}$.

34. Sachs H. Dichtungen. 2 Theil: Spruchgedichte. Leipzig, 1885. S. 257-259.

35. Hasse F.C.A. Die Geschichte der Lombardei. 3 Bänd. Dresden, 1828. S. 135.
36. Laukhard F.C. Leben und Schicksale, von ihm selbst beschrieben, und zur Warnung für Eltern und studierende Junglinge herausgeben. Zweite Teil. Halle, 1792.

37. Horatius. Opera. Edidit F. Klingner. Berolini : Walter de Gruyter, 2008. P. 13.

38. Martialis M.V. Epigrammaton libri. Leipzig, 1976.

39. Saint Augustine. The City of God against the Pagans : in 7 vol. / Engl. transl. by Sanford and McAllen Green. Cambridge Mass. : Harvard UP, 1965. Vol. 5. P. x-xi.

Чернишов В. В. Студентський гімн «Gaudeamus igitur...»: проблема походження та інтерпретації

Анотація. Статтю присвячено проблемі походження та інтерпретації студентської пісні «Гаудеамус» («Про короткочасність життя»). Проблемне поле дослідження включає низку пунктів: хронологічну проблему, походження та оригінальне призначення тексту, його джерела, соціальне й культурне середовище, у якому він виник і де проходила його еволюція, розмаїття намірів тих, хто так чи інакше зробив свій внесок у формування тексту цієї студентської пісні в її теперішній формі. Предметом окремого аналізу є розмаїття наявних версій «Gaudeamus igitur» та їх кореляція. Розглядаючи історію дослідження походження студентського гімну, автор доходить думки про необгрунтованість гіпотези середньовічного походження цього тексту. Натомість наводиться гіпотеза, що цей текст міг виникнути в XVII ст. в Німеччині, Італії або Нідерландах. Однак у ході дослідження автор доходить думки, що найвірогіднішим місцем появи зазначеного тексту варто вважати німецьку Сну. Що ж до визначення можливого автора «Gaudeamus igitur», то на цей час авторство тексту встановити не вдалося, автор залишається невідомим, а всі спроби розв'язати це питання наразі мають бути визнані незадовільними. Висловлено гіпотезу щодо колективного авторства гімну, а отже, у разі прийняття цієї гіпотези питання про особисте авторство цього тексту просто знімається. Другу частину статті присвячено авторській інтерпретації тексту «Gaudeamus igitur». Базовою тезою цієї інтерпретації є теза про ренесансний характер зазначеного тексту, що спирається на античну поетичну традицію, репрезентовану іменами Вергілія, Горація та Овідія (гуманісти доби Відродження вважали цю традицію еталонною). Наводиться думка, що великі латинські поети репрезентували ідеї грецьких філософів, насамперед Епікура та Пітагора, меншою мірою Платона, Арістотеля та неоплатонічної традиції, а лейтмотив цього тексту є переспівом Горацієвого мотиву «Carpe diem». Стверджується, що пісня символічно репрезентує людське життя - його інтелектуальну, приватну й соціально-політичну сфери 3 позиції студента, а в останній строфі позначає головні завади до щастя, яким проголошується «нехай пропадуть!».

Ключові слова: Гаудеамус, застольні пісні, студентські пісні, студентська субкультура Нового часу, студентська субкультура середніх віків. 